\title{
NEGARA HUKUM INDONESIA
}

\section{Nama Mahasiswa : Rebi Sandra \\ Email: rebisandra31@gmail.com \\ No BP: 2010003600245 \\ Perguruan Tinggi : Universitas eka sakti Padang}

\section{A. PENDAHULUAN}

Negara hukum rechtsstaat dan the rule of law merupakan istilah yang meskipun kelihatan sederhana, namun mengandung muatan sejarah pemikiran yang relatif panjang. Latar belakang timbulnya pemikiran negara hukum itu merupakan reaksi terhadap kesewenangan-wenangan di masa lampau.

Cita negara hukum untuk pertama kalinya dikemukakan oleh Plato dan kemudian pemikiran tersebut dipertegas oleh Aristoteles. Plato memiliki konsep bahwa "penyelenggaraan negara yang baik didasarkan pada pengaturan (hukum) yang baik yang disebut dengan istilah nomoi". Kemudian ide negara hukum populer kembali pada abad ke-17 sebagai akibat dari situasi politik di Eropa yang didominasi oleh absolutisme.Secara embrionik, gagasan negara hukum bermula dari Plato, ketika mengintroduksi konsep nomoi, sebagai karya tulis ketiga yang dibuat di usia tuanya. Gagasan Plato ini didukung oleh Aristoteles dalam bukunya Politica. Pengertian negara hukum menurut Aristoteles dikaitkan dengan arti dan perumusan yang masih melekat kepada "Polis". Dalam polis segala urusan negara dilakukan dengan musyawarah (ecclesia), dimana seluruh warga negaranya ikut serta ambil bagian dalam urusan penyelenggaraan negara. Oleh karena itu, meskipun konsep negara hukum menganut konsep universal, namun pada tataran implementasinya ternyata dipengaruhi oleh karakteristik negara dan manusianya yang beragam. Atas dasar itu, secara historis dan praktis konsep negara hukum banyak didasari oleh Al-Quran, Pancasila, dan Undang-Undang Dasar 1945 di Indonesia, dimana 
dalam Pasal 1 ayat (3) UUD 1945 secara tegas mengatakan bahwa negara Indonesia adalah negara hukum, sebagaimana dipahami dengan rechsstaat menurut Eropa Kontinental dan rule of law menurut Anglo Saxon. Menurut Bahder Johan Nasution yang dikutip dari Pamungkas Satya Putra bahwa istilah rechtsstaat pertama kali digunakan oleh Rudolf von Gneist dalam bukunya yang berjudul Das Englische Verwaltungsrecht, 1857.

Dalam buku itu digunakan istilah rechtsstaat untuk menunjuk sistem hukum yang berlaku di Inggris. Rudolf von Gneist lebih lanjut membahas rechtsstaat dalam bukunya yang berjudul Der Rechtsstaat. Berkenaan dengan ini Willem van der Vlugt, guru besar di Leiden dalam disertasinya yang berjudul De Rechtsstaat Volgens de Leer van Rudolf von Gneist menyatakan pendapatnya bahwa kepada Gneist lah seharusnya diberi penghormatan yang tadinya dengan kurang tepat diberikan kepada Montesquieu, sebagai seorang yang memopulerkan tata negara Inggris sebagai satu kesatuan yang hidup.Richard S. Kay, menjelaskan dengan kalimat yang hampir mirip yaitu rechtsstaat, sebagai pengaturan penataan hukum, mengandaikan keberadaan machtsstaat, perangkat kekuatan politik yang harus dikendalikan. Doktrin rule of law dianut oleh sistem anglo saxon yang digagas oleh Albert Venn Dicey menjelaskan dua hal terkait dengan rule of law yaitu pertama embrionik rule of law adalah kemahakuasaan atau supremasi tak terbantahkan di seluruh negara bagian dan pemerintah pusat. Kewenangan negara atau bangsa ini selama periode awal sejarah kita diwakili oleh kekuatan mahkota. Raja adalah sumber hukum dan pemelihara ketertiban. Pepatah pengadilan mengatakan bahwa tout fuit in luy et vient de lui al commencement (pada awalnya merupakan ekspresi dari fakta yang sebenarnya dan tidak diragukan lagi).

Supremasi kerajaan ini sekarang telah beralih ke kedaulatan parlemen yang telah menjadi pokok pembicaraan dari pasal-pasal di atas. Yang kedua dari embrionik rule of law yang 
berhubungan erat dengan yang pertama, yaitu peraturan atau supremasi hukum. Keunikan dari pemerintahan diungkapkan dengan baik dalam pandangan lama pengadilan: "La ley est le plus haute, inheritance, que le roy ad; car par la ley il même et teutes ses sujets sont rulés, et si la ley ne fuit; nul roi, et nul inheritance sera". Supremasi hukum ini, atau keamanan yang diberikan berdasarkan konstitusi Inggris terhadap hak-hak individu dilihat dari berbagai sudut pandang, membentuk pokok bahasan dari bagian dari rule of law. Pengamat asing dengan cara Inggris, seperti Voltaire, De Lolme, de Tocqueville atau Gneist, jauh lebih hebat daripada orang Inggris sendiri dengan fakta bahwa Inggris adalah negara yang diperintah berdasarkan supremasi hukum; dan kekaguman atau keheranan pada legalitas kebiasaan dan perasaan Inggris tidak ada tempat yang lebih baik diungkapkan daripada di bagian penasaran dari tulisan-tulisan Tocqueville, yang membandingkan Swiss dan Inggris tahun 1836 sehubungan dengan semangat yang menyelimuti hukum dan perilaku mereka.

\section{B. PEMBAHASAN}

Tata cara menjalankan kehidupan di hampir seluruh negara diatur oleh asas hukum, termasuk pula di Indonesia. Maka daripada itu, dalam kekuasaan pemerintahan, hukum berada di posisi paling atas. Sebab, Indonesia adalah negara hukum dan itu tercantum dalam pasal 1 ayat 3

UUD 1945. Negara yang berlandaskan hukum menggunakan aturan hukum untuk mencapai tujuan kehidupan bernegara. Menurut Johan Nasution dalam buku Negara Hukum dan Hak Asasi Manusia (2013), negara hukum adalah sebuah negara yang penyelenggaraan kekuasaan pemerintahannya berdasarkan atas hukum.

Sementara menurut guru besar hukum tata negara Jimly Asshiddiqie (2006), negara hukum disebut sebagai bentuk negara yang unik karena seluruh kehendak didasarkan atas hukum. Konsep negara yang tidak menggunakan hukum, tentu sangat berbeda dengan negara 
hukum. Sebab, untuk menetapkan dan mengatur, negara hukum memiliki sebuah puncak sistem berupa konstitusi atau UUD. Menurut pasal 1 ayat 3 UUD 1945, Indonesia merupakan negara yang berlandaskan hukum dalam mencari keputusan objektif dari pihak pemerintah dan rakyatnya. Berikut ini bunyi pasalnya: "Negara Indonesia adalah negara hukum.”.Secara umum, negara hukum seperti Indonesia memberikan seluruh kepercayaannya kepada kuasa negara yang berproses melalui hukum yang dianggap baik dan sifatnya adil bagi seluruh bagian negara. Mulai dari rakyat, hingga pihak pemerintahan yang memiliki jabatan di kekuasaan negara.

\section{Ciri-ciri Negara Hukum Menurut UUD 1945}

Setelah meninjau bentuk negara hukum Indonesia yang telah disebutkan pasal 1 ayat 3 UUD 1945, Azhary dalam buku Negara Hukum Indonesia, Analisis Yuridis Normatif Tentang Unsur-unsurnya (1995), mengungkapkan bahwa terdapat beberapa ciri yang dapat mendeskripsikan mengapa Indonesia termasuk dalam negara hukum.

Berikut ini ciri-ciri negara hukum menurut Azhary:

1. Hukum bersumber pada Pancasila;

2. Berkedaulatan rakyat;

3. Pemerintahan berdasarkan atas sistem konstitusi

4. Persamaan kedudukan di dalam hukum dan pemerintahan

5. Kekuasaan kehakiman yang bebas dari pengaruh kekuasaan lainnya

6. Pembentukan undang-undang oleh Presiden bersama-sama dengan DPR

7. Dianutnya sistem MPR.

\section{Konsep Negara Hukum Kontemporer}


Gagasan, cita, atau ide Negara Hukum, selain terkait dengan konsep 'rechtsstaat' dan 'the rule of law', juga berkaitan dengan konsep 'nomocracy' yang berasal dari perkataan 'nomos' dan 'cratos'. Perkataan nomokrasi itu dapat dibandingkan dengan 'demos' dan 'cratos' atau 'kratien' dalam demokrasi. 'Nomos' berarti norma, sedangkan 'cratos' adalah kekuasaan. Yang dibayangkan sebagai faktor penentu dalam penyelenggaraan kekuasaan adalah norma atau hukum. Karena itu, istilah nomokrasi itu berkaitan erat dengan ide kedaulatan hukum atau prinsip hukum sebagai kekuasaan tertinggi. Dalam istilah Inggeris yang dikembangkan oleh A.V. Dicey, hal itu dapat dikaitkan dengan prinsip "rule of law" yang berkembang di Amerika Serikat menjadi jargon "the Rule of Law, and not of Man". Yang sesungguhnya dianggap sebagai pemimpin adalah hukum itu sendiri, bukan orang. Dalam buku Plato berjudul "Nomoi" yang kemudian diterjemahkan ke dalam bahasa Inggeris dengan judul "The Laws"2, jelas tergambar bagaimana ide nomokrasi itu sesungguhnya telah sejak lama dikembangkan dari zaman Yunani Kuno.

Di zaman modern, konsep Negara Hukum di Eropah Kontinental dikembangkan antara lain oleh Immanuel Kant, Paul Laband, Julius Stahl, Fichte, dan lain-lain dengan menggunakan istilah Jerman, yaitu "rechtsstaat'. Sedangkan dalam tradisi Anglo Amerika, konsep Negara hukum dikembangkan atas kepeloporan A.V. Dicey dengan sebutan "The Rule of Law". Menurut Julius Stahl, konsep Negara Hukum yang disebutnya dengan istilah 'rechtsstaat' itu mencakup empat elemen penting, yaitu:

1. Perlindungan hak asasi manusia.

2. Pembagian kekuasaan. 
3. Pemerintahan berdasarkan undang-undang.

4. Peradilan tata usaha Negara.

Sedangkan A.V. Dicey menguraikan adanya tiga ciri penting dalam setiap Negara Hukum yang disebutnya dengan istilah "The Rule of Law”, yaitu:

1. Supremacy of Law.

2. Equality before the law.

3. Due Process of Law.

Keempat prinsip 'rechtsstaat' yang dikembangkan oleh Julius Stahl tersebut di atas pada pokoknya dapat digabungkan dengan ketiga prinsip 'Rule of Law' yang dikembangkan oleh A.V. Dicey untuk menandai ciri-ciri Negara Hukum modern di zaman sekarang. Bahkan, oleh "The International Commission of Jurist”, prinsip-prinsip Negara Hukum itu ditambah lagi dengan prinsip peradilan bebas dan tidak memihak (independence and impartiality of judiciary) yang di zaman sekarang makin dirasakan mutlak diperlukan dalam setiap negara demokrasi. Prinsip-prinsip yang dianggap ciri penting Negara Hukum menurut "The International Commission of Jurists" itu adalah:

1. Negara harus tunduk pada hukum.

2. Pemerintah menghormati hak-hak individu.

3. Peradilan yang bebas dan tidak memihak.

Profesor Utrecht membedakan ntara Negara Hukum Formil atau Negara Hukum Klasik, dan Negara Hukum Materiel atau Negara Hukum Modern3 . Negara Hukum Formil menyangkut pengertian hukum yang bersifat formil dan sempit, yaitu dalam arti peraturan perundang-undangan tertulis. Sedangkan yang kedua, yaitu Negara Hukum Materiel yang lebih mutakhir mencakup pula pengertian keadilan di dalamnya. Karena 
itu, Wolfgang Friedman dalam bukunya 'Law in a Changing Society' membedakan antara 'rule of law' dalam arti formil yaitu dalam arti 'organized public power', dan 'rule of law' dalam arti materiel yaitu 'the rule of just law'. Pembedaan ini dimaksudkan untuk menegaskan bahwa dalam konsepsi negara hukum itu, keadilan tidak serta-merta akan terwujud secara substantif, terutama karena pengertian orang mengenai hukum itu sendiri dapat dipengaruhi oleh aliran pengertian hukum formil dan dapat pula dipengaruhi oleh aliran pikiran hukum materiel. Jika hukum dipahami secara kaku dan sempit dalam arti peraturan perundang-undangan semata, niscaya pengertian negara hukum yang dikembangkan juga bersifat sempit dan terbatas serta belum tentu menjamin keadilan substantive. Karena itu, di samping istilah 'the rule of law' oleh Friedman juga dikembangikan istilah 'the rule of just law' untuk memastikan bahwa dalam pengertian kita tentang 'the rule of law' tercakup pengertian keadilan yang lebih esensiel daripada sekedar memfungsikan peraturan perundang-undangan dalam arti sempit. Kalaupun istilah yang digunakan tetap 'the rule of law', pengertian yang bersifat luas itulah yang diharapkan dicakup dalam istilah 'the rule of law' yang digunakan untuk menyebut konsepsi tentang Negara Hukum di zaman sekarang.

Namun demikian, terlepas dari perkembangan pengertian tersebut di atas, konsepsi tentang Negara Hukum di kalangan kebanyakan ahli hukum masih sering terpaku kepada unsur-unsur pengertian sebagaimana dikembangkan pada abad ke-19 dan abad ke-20. Sebagai contoh, tatkala merinci unsur-unsur pengertian Negara Hukum (Rechtsstaat), para ahli selalu saja mengemukakan empat unsur 'rechtsstaat', dimana unsurnya yang keempat adalah adanya 'administratieve rechtspraak' atau peradilan tata usaha Negara sebagai ciri pokok Negara Hukum. Tidak ada yang mengaitkan unsur 
pengertian Negara Hukum Modern itu dengan keharusan adanya kelembagaan atau setidak-tidaknya fungsi Mahkamah Konstitusi sebagai lembaga pengadilan tata Negara. Jawabannya ialah karena konsepsi Negara Hukum (Rechtsstaat) sebagaimana banyak dibahas oleh para ahli sampai sekarang adalah hasil inovasi intelektual hukum pada abad ke 19 ketika Pengadilan Administrasi Negara itu sendiri pada mulanya dikembangkan; sedangkan Mahkamah Konstitusi baru dikembangkan sebagai lembaga tersendiri di samping Mahkamah Agung atas jasa Professor Hans Kelsen pada tahun 1919, dan baru dibentuk pertama kali di Austria pada tahun 1920. Oleh karena itu, jika pengadilan tata usaha Negara merupakan fenomena abad ke-19, maka pengadilan tata negara adalah fenomena abad ke-20 yang belum dipertimbangkan menjadi salah satu ciri utama Negara Hukum kontemporer. Oleh karena itu, patut kiranya dipertimbangkan kembali untuk merumuskan secara baru konsepsi Negara Hukum modern itu sendiri untuk kebutuhan praktek ketatanegaraan pada abad ke-21 sekarang ini.

\section{Cita Negara Hukum Indonesia}

Dalam rangka merumuskan kembali ide-ide pokok konsepsi Negara Hukum itu dan pula penerapannya dalam situasi Indonesia dewasa ini, menurut pendapat saya, kita dapat merumuskan kembali adanya tiga-belas prinsip pokok Negara Hukum (Rechtsstaat) yang berlaku di zaman sekarang. Ketiga-belas prinsip pokok tersebut merupakan pilarpilar utama yang menyangga berdiri tegaknya satu negara modern sehingga dapat disebut sebagai Negara Hukum (The Rule of Law, ataupun Rechtsstaat) dalam arti yang sebenarnya, yaitu:

1. Supremasi Hukum (Supremacy of Law) 
Adanya pengakuan normatif dan empirik akan prinsip supremasi hukum, yaitu bahwa semua masalah diselesaikan dengan hukum sebagai pedoman tertinggi. Dalam perspektif supremasi hukum (supremacy of law), pada hakikatnya pemimpin tertinggi negara yang sesungguhnya, bukanlah manusia, tetapi konstitusi yang mencerminkan hukum yang tertinggi. Pengakuan normative mengenai supremasi hukum adalah pengakuan yang tercermin dalam perumusan hukum dan/atau konstitusi, sedangkan pengakuan empirik adalah pengakuan yang tercermin dalam perilaku sebagian terbesar masyarakatnya bahwa hukum itu memang 'supreme'. Bahkan, dalam republik yang menganut sistem presidential yang bersifat murni, konstitusi itulah yang sebenarnya lebih tepat untuk disebut sebagai 'kepala negara'. Itu sebabnya, dalam sistem pemerintahan presidential, tidak dikenal adanya pembedaan antara kepala Negara dan kepala pemerintahan seperti dalam sistem pemerintahan parlementer.

2. Persamaan dalam Hukum (Equality before the Law)

Adanya persamaan kedudukan setiap orang dalam hukum dan pemerintahan, yang diakui secara normative dan dilaksanakan secara empirik. Dalam rangka prinsip persamaan ini, segala sikap dan tindakan diskriminatif dalam segala bentuk dan manifestasinya diakui sebagai sikap dan tindakan yang terlarang, kecuali tindakantindakan yang bersifat khusus dan sementara yang dinamakan 'affirmative actions' guna mendorong dan mempercepat kelompok masyarakat tertentu atau kelompok warga masyarakat tertentu untuk mengejar kemajuan sehingga mencapai tingkat perkembangan yang 
sama dan setara dengan kelompok masyarakat kebanyakan yang sudah jauh lebih maju. Kelompok masyarakat tertentu yang dapat diberikan perlakuan khusus melalui 'affirmative actions' yang tidak termasuk pengertian diskriminasi itu misalnya adalah kelompok masyarakat suku terasing atau kelompok masyarakat hukum adapt tertentu yang kondisinya terbelakang. Sedangkan kelompok warga masyarakat tertentu yang dapat diberi perlakuan khusus yang bukan bersifat diskriminatif, misalnya, adalah kaum wanita ataupun anak-anak terlantar.

3. Asas Legalitas (Due Process of Law)

Dalam setiap Negara Hukum, dipersyaratkan berlakunya asas legalitas dalam segala bentuknya (due process of law), yaitu bahwa segala tindakan pemerintahan harus didasarkan atas peraturan perundang-undangan yang sah dan tertulis. Peraturan perundang-undangan tertulis tersebut harus ada dan berlaku lebih dulu atau mendahului tindakan atau perbuatan administrasi yang dilakukan. Dengan demikian, setiap perbuatan atau tindakan administrasi harus didasarkan atas aturan atau 'rules and procedures' (regels). Prinsip normative demikian nampaknya seperti sangat kaku dan dapat menyebabkan birokrasi menjadi lamban. Oleh karena itu, untuk menjamin ruang gerak bagi para pejabat administrasi negara dalam menjalankan tugasnya, maka sebagai pengimbang, diakui pula adanya prinsip 'frijs ermessen' yang memungkinkan para pejabat tata usaha negara atau administrasi negara mengembangkan dan menetapkan sendiri 'beleid-regels' ('policy rules') ataupun peraturanperaturan yang dibuat untuk kebutuhan internal (internal regulation) secara 
bebas dan mandiri dalam rangka menjalankan tugas jabatan yang dibebankan oleh peraturan yang sah.

4. Pembatasan Kekuasaan

Adanya pembatasan kekuasaan Negara dan organ-organ Negara dengan cara menerapkan prinsip pembagian kekuasaan secara vertikal atau pemisahan kekuasaan secara horizontal. Sesuai dengan hukum besi kekuasaan, setiap kekuasaan pasti memiliki kecenderungan untuk berkembang menjadi sewenangwenang, seperti dikemukakan oleh Lord Acton: "Power tends to corrupt, and absolute power corrupts absolutely". Karena itu, kekuasaan selalu harus dibatasi dengan cara memisah-misahkan kekuasaan ke dalam cabangcabang yang bersifat 'checks and balances' dalam kedudukan yang sederajat dan saling mengimbangi dan mengendalikan satu sama lain. Pembatasan kekuasaan juga dilakukan dengan membagi-bagi kekuasaan ke dalam beberapa organ yang tersusun secara vertical. Dengan begitu, kekuasaan tidak tersentralisasi dan terkonsentrasi dalam satu organ atau satu tangan yang memungkinkan terjadinya kesewenang-wenangan.

5. Organ-Organ Campuran Yang Bersifat Independen

Dalam rangka membatasi kekuasaan itu, di zaman sekarang berkembang pula adanya pengaturann kelembagaan pemerintahan yang bersifat 'independent', seperti bank sentral, organisasi tentara, dan organisasi kepolisian. Selain itu, ada pula lembaga-lembaga baru seperti Komisi Hak Asasi Manusia, Komisi Pemilihan Umum (KPU), Komisi Ombudsman Nasional (KON), Komisi Penyiaran Indonesia (KPI), dan lain sebagainya. 
Lembaga, badan atau organisasi-organisasi ini sebelumnya dianggap sepenuhnya berada dalam kekuasaan eksekutif, tetapi sekarang berkembang menjadi independen sehingga tidak lagi sepenuhnya merupakan hak mutlak seorang kepala eksekutif untuk menentukan pengangkatan ataupun pemberhentian pimpinannya. Independensi lembaga atau organ-organ tersebut dianggap penting untuk menjamin demokrasi, karena fungsinya dapat disalahgunakan oleh pemerintah untuk melanggengkan kekuasaan. Misalnya, fungsi tentara yang memegang senjata dapat dipakai untuk menumpang aspirasi prodemokrasi, bank sentral dapat dimanfaatkan untuk mengontrol sumber-sumber kekuangan yang dapat dipakai untuk tujuan mempertahankan kekuasaan, dan begitu pula lembaga atau organisasi lainnya dapat digunakan untuk kepentingan kekuasaan. Karena itu, independensi lembaga-lembaga tersebut dianggap sangat penting untuk menjamin prinsip negara hukum dan demokrasi.

6. Peradilan Bebas dan Tidak Memihak

Adanya peradilan yang bebas dan tidak memihak (independent and impartial judiciary). Peradilan bebas dan tidak memihak ini mutlak harus ada dalam setiap Negara Hukum. Dalam menjalankan tugas judisialnya, hakim tidak boleh dipengaruhi oleh siapapun juga, baik karena kepentingan jabatan (politik) maupun kepentingan uang (ekonomi). Untuk menjamin keadilan dan kebenaran, tidak diperkenankan adanya intervensi ke dalam proses pengambilan putusan keadilan oleh hakim, baik intervensi dari lingkungan kekuasaan eksekutif maupun legislative ataupun dari kalangan masyarakat dan 
media massa. Dalam menjalankan tugasnya, hakim tidak boleh memihak kepada siapapun juga kecuali hanya kepada kebenaran dan keadilan. Namun demikian, dalam menjalankan tugasnya, proses pemeriksaan perkara oleh hakim juga harus bersifat terbuka, dan dalam menentukan penilaian dan menjatuhkan putusan, hakim harus menghayati nilai-nilai keadilan yang hidup di tengah-tengah masyarakat. Hakim tidak hanya bertindak sebagai 'mulut' undangundang atau peraturan perundang-undangan, melainkan juga 'mulut' keadilan yang menyuarakan perasaan keadilan yang hidup di tengah-tengah masyarakat.

\section{Peradilan Tata Usaha Negara}

Meskipun peradilan tata usaha negara juga menyangkut prinsip peradilan bebas dan tidak memihak, tetapi penyebutannya secara khusus sebagai pilar utama Negara Hukum tetap perlu ditegaskan tersendiri. Dalam setiap Negara Hukum, harus terbuka kesempatan bagi tiap-tiap warga negara untuk menggugat keputusan pejabat administrasi Negara dan dijalankannya putusan hakim tata usaha negara (administrative court) oleh pejabat administrasi negara. Pengadilan Tata Usaha Negara ini penting disebut tersendiri, karena dialah yang menjamin agar warga negara tidak didzalimi oleh keputusankeputusan para pejabat administrasi negara sebagai pihak yang berkuasa. Jika hal itu terjadi, maka harus ada pengadilan yang menyelesaikan tuntutan keadilan itu bagi warga Negara, dan harus ada jaminan bahwa putusan hakim tata usaha Negara itu benar-benar djalankan oleh para pejabat tata usaha Negara yang bersangkutan. Sudah tentu, keberadaan hakim peradilan tata 
usaha negara itu sendiri harus pula dijamin bebas dan tidak memihak sesuai prinsip 'independent and impartial judiciary' tersebut di atas.

8. Peradilan Tata Negara (Constitutional Court)

Di samping adanya pengadilan tata usaha negara yang diharapkan memberikan jaminan tegaknya keadilan bagi tiap-tiap warga negara, Negara Hukum modern juga lazim mengadopsikan gagasan mahkamah konstitusi dalam sistem ketatanegaraannya, baik dengan pelembagaannya yang berdiri sendiri di luar dan sederajat dengan Mahkamah Agung ataupun dengan mengintegrasikannya ke dalam kewenangan Mahkamah Agung yang sudah ada sebelumnya. Pentingnya peradilan ataupun mahkamah konstitusi (constitutional court) ini adalah dalam upaya memperkuat sistem 'checks and balances' antara cabang-cabang kekuasaan yang sengaja dipisah-pisahkan untuk menjamin demokrasi. Misalnya, mahkamah ini diberi fungsi pengujian konstitusionalitas undang-undang yang merupakan produk lembaga legislatif, dan memutus berkenaan dengan berbagai bentuk sengketa antar lembaga negara yang mencerminkan cabang-cabang kekuasaan negara yang dipisahpisahkan. Keberadaan mahkamah konstitusi ini di berbagai negara demokrasi dewasa ini makin dianggap penting dan karena itu dapat ditambahkan menjadi satu pilar baru bagi tegaknya Negara Hukum modern.

9. Perlindungan Hak Asasi Manusia

Adanya perlindungan konstitusional terhadap hak asasi manusia dengan jaminan hukum bagi tuntutan penegakannya melalui proses yang adil. Perlindungan terhadap hak asasi manusia tersebut dimasyarakatkan secara 
luas dalam rangka mempromosikan penghormatan dan perlindungan terhadap hak-hak asasi manusia sebagai ciri yang penting suatu Negara Hukum yang demokratis. Setiap manusia sejak kelahirannya menyandang hak-hak dan kewajiban-kewajiban yang bersifat bebas dan asasi. Terbentuknya Negara dan demikian pula penyelenggaraan kekuasaan suatu Negara tidak boleh mengurangi arti atau makna kebebasan dan hak-hak asasi kemanusiaan itu. Karena itu, adanya perlindungan dan penghormatan terhadap hak-hak asasi manusia itu merupakan pilar yang sangat penting dalam setiap Negara yang disebut sebagai Negara Hukum. Jika dalam suatu Negara, hak asasi manusia terabaikan atau dilanggar dengan sengaja dan penderitaan yang ditimbulkannya tidak dapat diatasi secara adil, maka Negara yang bersangkutan tidak dapat disebut sebagai Negara Hukum dalam arti yang sesungguhnya.

10. Bersifat Demokratis (Democratische Rechtsstaat)

Dianut dan dipraktekkannya prinsip demokrasi atau kedaulatan rakyat yang menjamin peranserta masyarakat dalam proses pengambilan keputusan kenegaraan, sehingga setiap peraturan perundang-undangan yang ditetapkan dan ditegakkan mencerminkan nilai-nilai keadilan yang hidup di tengah masyarakat. Hukum dan peraturan perundang-undangan yang berlaku, tidak boleh ditetapkan dan diterapkan secara sepihak oleh dan/atau hanya untuk kepentingan penguasa secara bertentangan dengan prinsip-prinsip demokrasi. Karena hukum tidak dimaksudkan hanya menjamin kepentingan segelintir orang yang berkuasa, melainkan menjamin kepentingan akan rasa adil bagi 
semua orang tanpa kecuali. Dengan demikian, cita negara hukum (rechtsstaat) yang dikembangkan bukanlah 'absolute rechtsstaat', melainkan 'democratische rechtsstaat' atau negara hukum yang demokratis. Dalam setiap Negara Hukum yang bersifat nomokratis harus dijamin adanya demokrasi, sebagaimana di dalam setiap Negara Demokrasi harus dijamin penyelenggaraannya berdasar atas hukum.

11. Berfungsi sebagai Sarana Mewujudkan Tujuan Bernegara (Welfare Rechtsstaat)

Hukum adalah sarana untuk mencapai tujuan yang diidealkan bersama. Cita-cita hukum itu sendiri, baik yang dilembagakan melalui gagasan negara demokrasi (democracy) maupun yang diwujudkan melalaui gagasan negara hukum (nomocrasy) dimaksudkan untuk meningkatkan kesejahteraan umum. Bahkan sebagaimana cita-cita nasional Indonesia yang dirumuskan dalam Pembukaan UUD 1945, tujuan bangsa Indonesia bernegara adalah dalam rangka melindungi segenap bangsa Indonesia dan seluruh tumpah darah Indonesia, memajukan kesejahteraan umum, mencerdaskan kehidupan bangsa, dan ikut melaksanakan ketertiban dunia berdasarkan kemerdekaan, perdamaian abadi dan keadilan sosial. Negara Hukum berfungsi sebagai sarana untuk mewujudkan dan mencapai keempat tujuan bernegara Indonesia itu. Dengan demikian, pembangunan negara Indonesia tidak terjebak menjadi sekedar 'rule-driven', melainkan 'mission driven', yang didasarkan atas aturan hukum.

12. Transparansi dan Kontrol Sosial 
Adanya transparansi dan kontrol sosial yang terbuka terhadap setiap proses pembuatan dan penegakan hukum, sehingga kelemahan dan kekurangan yang terdapat dalam mekanisme kelembagaan resmi dapat dilengkapi secara komplementer oleh peranserta masyarakat secara langsung (partisipasi langsung) dalam rangka menjamin keadilan dan kebenaran. Adanya partisipasi langsung ini penting karena sistem perwakilan rakyat melalui parlemen tidak pernah dapat diandalkan sebagai satu-satunya saluran aspirasi rakyat. Karena itulah, prinsip 'representation in ideas' dibedakan dari 'representation in presence', karena perwakilan fisik saja belum tentu mencerminkan keterwakilan gagasan atau aspirasi. Demikian pula dalam penegakan hukum yang dijalankan oleh aparatur kepolisian, kejaksaan, pengacara, hakim, dan pejabat lembaga pemasyarakatan, semuanya memerlukan kontrol sosial agar dapat bekerja dengan efektif, efisien serta menjamin keadilan dan kebenaran.

\section{Ber-Ketuhanan Yang Maha Esa}

Khusus mengenai cita Negara Hukum Indonesia yang berdasarkan Pancasila, ide kenegaraan kita tidak dapat dilepaskan pula dari nilai Ketuhanan Yang Maha Esa yang merupakan sila pertama dan utama Pancasila.

Karena itu, di samping ke-12 ciri atau unsur yang terkandung dalam gagasan Negara Hukum Modern seperti tersebut di atas, unsur ciri yang ketigabelas adalah bahwa Negara Hukum Indonesia itu menjunjung tinggi nilai-nilai ke-Maha Esaan dan ke-Maha Kuasa-an Tuhan. Artinya, diakuinya 
prinsip supremasi hukum tidak mengabaikan keyakinan mengenai ke-Maha Kuasa-an Tuhan Yang Maha Esa yang diyakini sebagai sila pertama dan utama dalam Pancasila. Karena itu, pengakuan segenap bangsa Indonesia mengenai kekuasaan tertinggi yang terdapat dalam hukum konstitusi di satu segi tidak boleh bertentangan dengan keyakinan segenap warga bangsa mengenai prinsip dan nilai-nilai ke-Maha-Kuasa-an Tuhan Yang Maha Esa itu, dan di pihak lain pengakuan akan prinsip supremasi hukum itu juga merupakan pengejawantahan atau ekspresi kesadaran rasional kenegaraan atas keyakinan pada Tuhan Yang Maha Esa yang menyebabkan setiap manusia Indonesia hanya memutlakkan Yang Esa dan menisbikan kehidupan antar sesama warga yang bersifat egaliter dan menjamin persamaan dan penghormatan atas kemajemukan dalam kehidupan bersama dalam wadah Negara Pancasila.

\section{PENUTUP}

Dalam sistem konstitusi Negara kita, cita Negara Hukum itu menjadi bagian yang tak terpisahkan dari perkembangan gagasan kenegaraan Indonesia sejak kemerdekaan. Meskipun dalam pasal-pasal UUD 1945 sebelum perubahan, ide Negara hukum itu tidak dirumuskan secara eksplisit, tetapi dalam Penjelasan ditegaskan bahwa Indonesia menganut ide 'rechtsstaat', bukan 'machtsstaat'. Dalam Konstitusi RIS Tahun 1949, ide negara hukum itu bahkan tegas dicantumkan. Demikian pula dalam UUDS Tahun 1950, kembali rumusan bahwa Indonesia adalah negara hukum dicantumkan dengan tegas. Oleh karena itu, dalam Perubahan Ketiga tahun 2001 terhadap UUD Negara Republik Indonesia Tahun 1945, ketentuan mengenai ini kembali dicantumkan tegas dalam Pasal 1 ayat (3) yang berbunyi: "Negara Indonesia adalah Negara 
Hukum". Kiranya, cita negara hukum yang mengandung 13 ciri seperti uraian di atas itulah ketentuan Pasal 1 ayat (3) UUD Negara Republik Indonesia Tahun 1945 itu sebaiknya kita pahami.

Demikianlah beberapa catatan ringkas tentang Negara Hukum Indonesia. Terbentuknya Mahkamah Konstitusi di satu segi menjadi salah satu ciri penting konsep Negara Hukum Indonesia pasca Perubahan Keempat Undang-Undang Dasar Negara Republik Indonesia Tahun 1945, dan di pihak lain, keberadaannya juga penting untuk merealisasikan perwujudan cita-cita Negara Hukum itu sendiri, dimulai dengan mengawal tegaknya konstitusi sebagai hukum yang tertinggi (the supreme law of the land). Mahkamah Konstitusi mempunyai kedudukan yang penting sebagai salah satu organ konstitusional pelaksana kekuasaan kehakiman yang merdeka di samping dan sederajat dengan Mahkamah Agung. Mahkamah Konstitusi mempunyai fungsi mengawal dan menjaga agar konstitusi sebagai hukum tertinggi dapat ditaati dan ditegakan dengan setegak-tegaknya, sekaligus dalam rangka mengendalikan, mengawal dan mengarahkan proses demokrasi kehidupan kenegaraan kita berdasarkan Undang-Undang Dasar Negara Republik Indonesia Tahun 1945. Sebagai pengawal konstitusi dan pengarah demokrasi, Mahkamah Konstitusi juga berfungsi sebagai penafsir tertinggi atas Undang-Undang Dasar melalui putusan-putusannya sebagaimana mestinya. Karena itu, dapat dikatakan kedudukan dan peranan lembaga ini sangat penting dan strategis dalam rangka bekerjanya sistem ketatanegaraan Republik Indonesia di masa yang akan datang, guna mendukung upaya membangun kehidupan kebangsaan dan kenegaraan kita yang semakin demokratis, damai, sejahtera, mandiri, bermartabat, dan berkeadilan.

\section{DAFTAR PUSTAKA}


Darmini Roza dan Laurensius Arliman S, Peran Pemerintah Daerah Di Dalam Melindungi Hak Anak Di Indonesia, Masalah-Masalah Hukum, Volume 47, Nomor 1, 2018. https://doi.org/10.14710/mmh.47.1.2018.10-21

Laurensius Arliman S, Peranan Metodologi Penelitian Hukum di Dalam Perkembangan Ilmu Hukum di Indonesia, Soumatera Law Review, Volume 1, Nomor 1, 201. http://doi.org/10.22216/soumlaw.v1i1.3346.

Laurensius Arliman S, Peran Badan Permusyawaratan Desa di Dalam Pembangunan Desa dan Pengawasan Keuangan Desa, Padjadjaran Journal of Law, Volume 4, Nomor 3, 2017. https://doi.org/10.15408/jch.v4i2.3433.

Laurensius Arliman S, Penanaman Modal Asing Di Sumatera Barat Berdasarkan UndangUndang Nomor 25 Tahun 2007 Tentang Penanaman Modal, Supremasi Hukum, Volume 1, Nomor 1, 2018. http://dx.doi.org/10.36441/hukum.vli01.102 .

Laurensius Arliman S, Memperkuat Kearifan Lokal Untuk Menangkal Intoleransi Umat Beragama Di Indonesia, Ensiklopedia of Journal, Volume 1, Nomor 1, 2018, https://doi.org/10.33559/eoj.v1i1.18.

Laurensius Arliman S, Perkawinan Antar Negara Di Indonesia Berdasarkan Hukum Perdata Internasional, Kertha Patrika, Volume 39, Nomor 3, 2017, https://doi.org/10.24843/KP.2017.v39.i03.p03.

Laurensius Arliman S, Partisipasi Masyarakat Di Dalam Pengelolaan Uang Desa PascaUndangUndang Nomor 6 Tahun 2014 Tentang Desa, Jurnal Arena Hukum, Volume 12, Nomor 2, 2019, https://doi.org/10.21776/ub.arenahukum.2019.01202.5.

Laurensius Arliman S, Mewujudkan Penegakan Hukum Yang Baik Di Negara Hukum Indonesia, Dialogica Jurnalica, Volume 11, Nomor 1, 2019, https://doi.org/10.28932/di.v11i1.1831.

Laurensius Arliman S, Mediasi Melalui Pendekatan Mufakat Sebagai Lembaga Alternatif Penyelesaian Sengketa Untuk Mendukung Pembangunan Ekonomi Nasional, UIR Law Review, Volume 2, Nomor 2, 2018, https://doi.org/10.25299/uirlrev.2018.vol2(02).1587

Laurensius Arliman S, Peranan Filsafat Hukum Dalam Perlindungan Hak Anak Yang Berkelanjutan Sebagai Bagian Dari Hak Asasi Manusia, Doctrinal, Volume 1, Nomor 2,2016.

Laurensius Arliman S, Ni Putu Eka Dewi, Protection of Children and Women's Rights in Indonesiathrough International Regulation Ratification, Journal of Innovation, Creativity and Change Volume 15, Nomor 6, 2021.

Laurensius Arliman S, Gagalnya Perlindungan Anak Sebagai Salah Satu Bagian Dari Hak Asasi Manusia Oleh Orang Tua Ditinjau Dari Mazhab Utilitarianisme, Jurnal Yuridis, Volume 3, Nomor 2, 2016, http://dx.doi.org/10.35586/.v3i2.180.

Laurensius Arliman S, Tantangan Pendidikan Kewarganegaraan Pada Revolusi 4.0, Jurnal Ensiklopedia Sosial Review, Volume 2, Nomor 3, $2020 .$. 
